\title{
Peran Media Pembelajaran dalam Pendidikan Islam
}

\author{
Moh. Irmawan Jauhari \\ Dosen Tetap pada STAI-Ma'arif Kendal Ngawi \\ Email: irmawanj@gmail.com
}

\begin{abstract}
Abstrak
Dunia pendidikan dewasa ini mengalami perkembangan luar biasa. Masuknya teknologi semakin memudahkan para guru dalam menyampaikan materi. Terlebih kehadiran teknologi berbasis informatika dan jaringan, mampu memberikan warna lain dalam dunia pembelajaran. Keadaan ini pada satu sisi merupakan nilai positif dalam dunia pembelajaran. Namun dengan bergesernya peran guru, maka ada banyak hal yang patut dipertimbangkan dengan kehadiran beberapa media dalam pendidikan. Mengingat meskipun media bisa melengkapi beberapa kelemahan yang dimiliki guru, namun bukan berarti media bisa memainkan peran menjadi figur dan tauladan bagi para murid.
\end{abstract}

Kata kunci: Media Pembelajaran, Pendidikan Islam.

\section{A. Pendahuluan}

Kegiatan Belajar Mengajar (KBM) merupakan sebuah proses penyampaian pesan atau informasi yang disampaikan oleh seorang tenaga pengajar atau pendidik (guru) kepada pihak yang diajar atau terdidik (murid). Menurut paradigma kajian Ilmu Komunikasi, penyampaiaan pesan dari komunikator kepada komunikan tersebut akan dinilai efektif dan berhasil apabila terjadi efek serta timbal balik dari pihak penerima pesan. ${ }^{1}$ Dalam arti, pihak komunikan mengalami suatu perubahan dalam dirinya, baik secara afektif(perasaan), kognitif (pengetahuan) maupun behavior (tingkah laku). Seiring perkembangan teknologi, dalam komunikasi proses penyampaian pesan, baik itu secara verbal maupun non verbal kerapkali meenggunakan media sebagai saluran pesan yang tujuannya agar proses transformasi informasi berjalan efektif dan berhasil.

Penggunaan media dinilai memiliki tingkat efektivitas yang tinggi terhadap proses komunikasi daripada tanpa melibatkan media. Dalam KBM, penggunaan media dalam kegiatan penyampaian informasi dari

${ }^{1}$ M. Linggar Anggoro, Teori Dan Profesi Kehumasan Serta Aplikasinya Di Indonesia (Jakarta: Bumi Aksara, 2001), hal 2. 
pendidik/guru kepada terdidik/murid disebut sebagai media pendidikan, juga dapat dikatakan sebagai alat bantu proses KBM. Dewasa ini telah terjadi pergeseran paradigma dalam pembelajaran ke arah paradigma konstruktivisme. Menurut pandangan ini bahwa pengetahuan tidak begitu saja bisa ditransfer oleh guru ke pikiran siswa, tetapi pengetahuan tersebut dikonstruksi di dalam pikiran siswa itu sendiri. ${ }^{2}$ Guru bukanlah satusatunya sumber belajar bagi siswa (teacher centered), tetapi yang lebih diharapkan adalah bahwa pembelajaran berpusat pada siswa (student centered). Dalam kondisi seperti ini, guru atau pengajar lebih banyak berfungsi sebagai fasilitator pembelajaran. Jadi, siswa sebaiknya secara aktif berinteraksi dengan sumber belajar, berupa lingkungan. Untuk mengatasi kemungkinan hambatan-hambatan yang terjadi selama proses penafsiran dan agar pembelajaran dapat berlangsung secara efektif, maka sedapat mungkin dalam penyampaian pesan (isi/materi ajar) dibantu dengan menggunakan media pembelajaran. Diharapkan dengan pemanfaatan sumber belajar berupa media pembelajaran, proses komunikasi dalam kegiatan belajar mengajar berlangsung lebih efektif dan efisien. ${ }^{3}$ Perkembangan ilmu dan teknologi semakin mendorong usahausaha ke arah pembaharuan dalam memanfaatkan hasil-hasil teknologi dalam pelaksanaan pembelajaran. Dalam melaksanakan tugasnya, guru diharapkan dapat menggunakan alat atau bahan pendukung proses pembelajaran, dari alat yang sederhana sampai alat yang canggih (sesuai dengan perkembangan dan tuntutan jaman). Bahkan mungkin lebih dari itu, guru diharapkan mampu mengembangkan keterampilan membuat media pembelajarannya sendiri. Oleh karena itu, guru (pengajar) harus memiliki pengetahuan dan pemahaman yang cukup tentang media pembelajaran.

Artikel ini mencoba mengupas peran media lebih jauh. Seputar arti media, posisnya, fungsi, klasifikasi, dan karakteristik beberapa jenis media, untuk mendapatkan gambaran tentang hakikat media dalam Pendidikan Islam.

\section{B. Pembahasan}

1. Makna Media Dalam Pendidikan Islam

Media (bentuk jamak dari kata medium), merupakan kata yang berasal dari bahasa latin medius, yang secara harfiah berarti 'tengah', 'perantara' atau 'pengantar', kata media, berasal dari bahasa Latin, bentuk jamak dari medium secara harfiah berarti perantara atau pengantar. ${ }^{4}$ Media adalah suatu alat yang dipakai sebagai saluran

\footnotetext{
${ }^{2}$ www.wordpress.com pendidikan konstruktivisme,diunduh tgl 12-12-2015.
}

${ }^{3}$ A. Arsyad, Media Pembelajaran, (Jakarta:Grafindo Persada, 2002 ), hal.6

${ }^{4}$ A. Arsyad, Media Pembelajaran, ........... hal. 2. 
(channel) untuk menyampaikan pesan (message) atau informasi dari suatu sumber (resource) kepada penerimanya (reciver). ${ }^{5}$

Santoso S. Hamijoyo, sebagaimana dikutip kembali oleh Sadiman mengatakan bila, media adalah semua bentuk perantara yang dipakai orang penyebar ide, sehingga ide atau gagasan itu sampai pada penerima. ${ }^{6}$ Media pengajaran pada hakekatnya hanya merupakan alat yang berfungsi untuk menvisualisasikan konsep tertentu. ${ }^{7}$

Dari beberapa literature, tidak terdapat perbedaan pengertian antara alat dan media pendidikan, Zakiah Darajat menyebutkan pengertian alat pendidikan sama dengan media pendidikan yaitu lebih bermakna sebagai sebagai sarana pendidikan. ${ }^{8}$ Oleh karena itu, media dapat diartikan sebagai perantara atau pengantar pesan dari pengirim ke penerima pesan. Media dapat berupa sesuatu bahan (software) dan/atau alat (hardware). Sedangkan menurut Gerlach \& Ely sebagaimana dikutip kembali oleh Arsyad, bahwa media jika dipahami secara garis besar adalah manusia, materi, atau kejadian yang membangun kondisi, yang menyebabkan siswa mampu memperoleh pengetahuan, keterampilan, atau sikap. ${ }^{9}$ Jadi menurut pengertian ini, guru, teman sebaya, buku teks, lingkungan sekolah dan luar sekolah, bagi seorang siswa merupakan media. Pengertian ini sejalan dengan batasan yang disampaikan oleh Gagne, sebagaimana dikutip kembali oleh yang menyatakan bahwa media merupakan berbagai jenis komponen dalam lingkungan siswa yang dapat merangsang untuk belajar. ${ }^{10}$

Banyak batasan tentang media, Association of Education and Communication Technology (AECT) memberikan pengertian tentang media sebagai segala bentuk dan saluran yang digunakan untuk menyampaikan pesan dan informasi.11 Dalam hal ini terkandung pengertian sebagai medium atau mediator, yaitu mengatur hubungan yang efektif antara dua pihak utama dalam proses belajar -siswa dan isi pelajaran. Sebagai mediator, dapat pula mencerminkan suatu pengertian bahwa dalam setiap sistem pengajaran, mulai dari guru sampai kepada peralatan yang paling canggih dapat disebut sebagai media.

Dalam dunia pendidikan, sering kali istilah alat bantu atau media komunikasi digunakan secara bergantian atau sebagai pengganti istilah

\footnotetext{
${ }^{5}$ Rosady Ruslan, Manajemen Public Relations Dan Media Komunikasi (Jakarta: Raja Grafindo Persada, 2007), 16.

6 Sadiman A.S. dkk, Media Pendidikan: Pengertian, Pengembangan Dan Pemanfaatannya, (Jakarta: Rajawali, 1990), hal. 3.

7 O. Hamalik, Media Pendidikan, (Bandung: Citra Aditya Bakti, 1994), hal. 5.

8 Zakiah Darajat, Ilmu Pendidikan Islam, (Jakarta: Bumi Aksara, 1984), hal. 23.

${ }^{9}$ A. Arsyad, Media Pembelajaran, .........., hal. 2.

${ }^{10}$ N. Sudjana \& Rivai, Media Pengajaran, (Bandung: Sinar Baru Bandung, 1992), hal. 6

${ }^{11}$ www.wordpress.com media pembelajaran. Diunduh tgl 14 Januari 2015.
} 
media pendidikan (pembelajaran). Seperti yang dikemukakan oleh Hamalik bahwa dengan penggunaan alat bantu berupa media komunikasi, hubungan komunikasi guru dan murid akan dapat berjalan dengan lancar dan dengan hasil yang maksimal. ${ }^{12}$ Dalam pengertian ini, buku/modul, tape recorder, kaset, video recorder, camera video, televisi, radio, film, slide, foto, gambar, dan komputer adalah merupakan media pembelajaran. Menurut National Education Association -NEAsebagaimana dikutip kembali oleh Sadiman dkk., media adalah bentukbentuk komunikasi baik yang tercetak maupun audio visual beserta peralatannya. ${ }^{13}$

Berdasarkan batasan-batasan mengenai media seperti tersebut di atas, maka dapat dikatakan bahwa media pembelajaran adalah segala sesuatu yang menyangkut software dan hardware yang dapat digunakan untuk meyampaikan isi materi ajar dari sumber belajar ke murid (individu atau kelompok), yang dapat merangsang pikiran, perasaan, perhatian dan minat sedemikian rupa sehingga proses belajar (di dalam/di luar kelas) menjadi lebih efektif.

2. Posisi Media Dalam Pendidikan Islam

Bruner mengungkapkan, sebagaimana dikutip kembali oleh Sadiman dkk., ada tiga tingkatan utama modus belajar, seperti: enactive (pengalaman langsung), iconic (pengalaman piktorial atau gambar), dan symbolic (pengalaman abstrak). ${ }^{14}$ Pemerolehan pengetahuan dan keterampilan serta perubahan sikap dan perilaku dapat terjadi karena adanya interaksi antara pengalaman baru dengan pengalaman yang telah dialami sebelumnya melalui proses belajar. Sebagai ilustrasi misalnya, belajar untuk memahami apa dan bagaimana mencangkok. Dalam tingkatan pengalaman langsung, untuk memperoleh pemahaman pebelajar secara langsung mengerjakan atau membuat cangkokan. Pada tingkatan kedua, iconic, pemahaman tentang mencangkok dipelajari melalui gambar, foto, film atau rekaman video. Selanjutnya pada tingkatan pengalaman abstrak, siswa memahaminya lewat membaca atau mendengar dan mencocokkannya dengan pengalaman melihat orang mencangkok atau dengan pengalamannya sendiri.

Dalam proses belajar mengajar sebaiknya diusahakan agar terjadi variasi aktivitas yang melibatkan semua alat indera peserta didik. Semakin banyak alat indera yang terlibat untuk menerima dan mengolah informasi (isi pelajaran), semakin besar kemungkinan isi pelajaran tersebut dapat dimengerti dan dipertahankan dalam ingatan peserta

12 O. Hamalik, Media Pendidikan,........, hal. 8.

${ }^{13}$ Sadiman A.S. dkk, Media Pendidikan: Pengertian, Pengembangan Dan Pemanfaatannya,.........., hal. 9.

14 Ibid, 30 . 
didik. Jadi agar pesan-pesan dalam materi yang disajikan dapat diterima dengan mudah (atau pembelajaran berhasil dengan baik), maka guru harus berupaya menampilkan stimulus yang dapat diproses dengan berbagai indera murid.

Media pembelajaran merupakan suatu perantara seperti apa yang dimaksud pada pernyataan di atas. Dalam kondisi ini, media yang digunakan memiliki posisi sebagai alat bantu dalam kegiatan pembelajaran, yaitu alat bantu mengajar bagi guru (teaching aids). Misalnya alat-alat grafis, photografis, atau elektronik untuk menangkap, memproses, dan menyusun kembali informasi visual atau verbal. Sebagai alat bantu dalam mengajar, media diharapkan dapat memberikan pengalaman kongkret, motivasi belajar, mempertinggi daya serap dan retensi belajar siswa. Sehingga alat bantu yang banyak dan sering digunakan adalah alat bantu visual, seperti gambar, model, objek tertentu, dan alat-alat visual lainnya. Oleh karena dianggap sebagai alat bantu, guru atau orang yang membuat media tersebut kurang memperhatikan aspek disainnya, pengembangan pembelajarannya, dan evaluasinya.

Dengan kemajuan teknologi di berbagai bidang, misalnya dalam teknologi komunikasi dan informasi pada saat ini, media pembelajaran memiliki posisi sentral dalam proses belajar dan bukan semata-mata sebagai alat bantu. Media pembelajaran memainkan peran yang cukup penting untuk mewujudkan kegiatan belajar menjadi lebih efektif dan efisien. Sehingga penggunaan media pembelajaran dikaitkan dengan apa-apa saja yang dapat dilakukan oleh media, yang mungkin tidak mampu dilakukan oleh guru (atau guru melakukannya kurang efisien). Dengan kehadiran media pembelajaran maka posisi guru bukan lagi sebagai satu-satunya sumber belajar, tetapi sebagai fasilitator. Bahkan pada saat ini media telah diyakini memiliki posisi sebagai sumber belajar yang menyangkut keseluruhan lingkungan di sekitar pebelajar. Meski kemudian hal ini menimbulkan perdebatan yang cukup pelik. Bagaimanapun, kerja mesin tidak dapat menggantikan peran pembentukan karakter yang tengah dilakukan oleh guru. Mesin tidak mampu memberikan contoh praksis atas sebuah teori, namun lebih pada penyajian data dan fakta.

Hasil belajar seseorang diperoleh mulai dari pengalaman berdasarkan kenyataan yang ada di lingkungan hidupnya, kemudian melalui benda-benda tiruan, dan selanjutnya sampai kepada lambanglambang verbal (abstrak). Untuk kondisi seperti inilah kehadiran media pembelajaran sangat bermanfaat. Dalam posisinya yang sedemikian rupa, media akan dapat merangsang keterlibatan beberapa alat indera. 
Di samping itu, memberikan solusi untuk memecahkan persoalan berdasarkan tingkat keabstrakan pengalaman yang dihadapi murid.

3. Fungsi Media Dalam Pendidikan Islam

Keefektifan proses belajar mengajar (pembelajaran) sangat dipengaruhi oleh faktor metode dan media pembelajaran yang digunakan. Keduanya saling berkaitan, di mana pemilihan metode tertentu akan berpengaruh terhadap jenis media yang akan digunakan. Dalam arti bahwa harus ada kesesuaian di antara keduanya untuk mewujudkan tujuan pembelajaran. Walaupun ada hal-hal lain yang juga perlu diperhatikan dalam pemilihan media, seperti: konteks pembelajaran, karakteristik pebelajar, dan tugas atau respon yang diharapkan dari murid. ${ }^{15}$ Dengan demikian, penataan pembelajaran (iklim, kondisi, dan lingkungan belajar) yang dilakukan oleh seorang pengajar dipengaruhi oleh peran media yang digunakan.

Pemanfaatan media dalam pembelajaran dapat membangkitkan keinginan dan minat baru, meningkatkan motivasi dan rangsangan kegiatan belajar, dan bahkan berpengaruh secara psikologis kepada siswa. ${ }^{16}$ Selanjutnya diungkapkan bahwa penggunaan media pengajaran akan sangat membantu keefektifan proses pembelajaran dan penyampaian informasi (pesan dan isi pelajaran) pada saat itu. Kehadiran media dalam pembelajaran juga dapat membantu peningkatan pemahaman siswa, penyajian data/informasi lebih menarik dan terpercaya, memudahkan penafsiran data, dan memadatkan informasi. Jadi dalam hal ini dikatakan bahwa fungsi media adalah sebagai alat bantu dalam kegiatan belajar mengajar. ${ }^{17}$

Sadiman dkk menyampaikan fungsi media (media pendidikan) secara umum adalah sebagai berikut:

a. Memperjelas penyajian pesan agar tidak terlalu bersifat visual;

b. Mengatasi keterbatasan ruang, waktu, dan daya indera, misal objek yang terlalu besar untuk dibawa ke kelas dapat diganti dengan gambar, slide, dsb., peristiwa yang terjadi di masa lalu bisa ditampilkan lagi lewat film, video, fota atau film bingkai;

c. Meningkatkan kegairahan belajar, memungkinkan siswa belajar sendiri berdasarkan minat dan kemampuannya, dan mengatasi sikap pasif siswa; dan

15 Arsyad, Media Pembelajaran ,........., hal 41.

16 O. Hamalik, Media Pembelajaran,........, hal18.

17 Ramayulis dan Syamsul Nizar, Filsafat Pendidikan Islam, (Jakarta: Kalam Mulia, 2009), hal. 19.

- Moh. Irmawan Jauhari - 73 
d. Memberikan rangsangan yang sama, dapat menyamakan pengalaman dan persepsi siswa terhadap isi pelajaran. ${ }^{18}$

Fungsi media, khususnya media visual juga dikemukakan oleh Levie dan Lentz, seperti yang dikutip kembali oleh Arsyad, bahwa media tersebut memiliki empat fungsi yaitu: fungsi atensi, fungsi afektif, fungsi kognitif, dan fungsi kompensatoris. ${ }^{19}$ Dalam fungsi atensi, media visual dapat menarik dan mengarahkan perhatian siswa untuk berkonsentrasi kepada isi pelajaran. Fungsi afektif dari media visual dapat diamati dari tingkat antusias siswa ketika belajar (membaca) teks bergambar. Dalam hal ini gambar atau simbol visual dapat menggugah emosi dan sikap siswa. Berdasarkan temuan-temuan penelitian diungkapkan bahwa fungsi kognitif media visual melalui gambar atau lambang visual dapat mempercepat pencapaian tujuan pembelajaran untuk memahami dan mengingat pesan/informasi yang terkandung dalam gambar atau lambang visual tersebut.

Fungsi kompensatoris media pembelajaran adalah memberikan konteks kepada siswa yang kemampuannya lemah dalam mengorganisasikan dan mengingat kembali informasi dalam teks. Dengan kata lain bahwa media pembelajaran ini berfungsi untuk mengakomodasi siswa yang lemah dan lambat dalam menerima dan memahami isi pelajaran yang disajikan dalam bentuk teks (disampaikan secara verbal).

Dengan menggunakan istilah media pengajaran, Sudjana dan Rivai mengemukakan beberapa manfaat media dalam proses belajar siswa, yaitu:

a. Dapat menumbuhkan motivasi belajar siswa karena pengajaran akan lebih menarik perhatian mereka;

b. Makna bahan pengajaran akan menjadi lebih jelas sehingga dapat dipahami siswa dan memungkinkan terjadinya penguasaan serta pencapaian tujuan pengajaran;

c. Metode mengajar akan lebih bervariasi, tidak semata-mata didasarkan atas komunikasi verbal melalui kata-kata;

d. Siswa lebih banyak melakukan aktivitas selama kegiatan belajar, tidak hanya mendengarkan tetapi juga mengamati, mendemonstrasikan, melakukan langsung, dan memerankan. ${ }^{20}$

\footnotetext{
${ }^{18}$ Sadiman, Media Pendidikan: Pengertian, Pengembangan Dan Pemanfaatannya,........, hal. 20.

${ }^{19}$ Arsyad, Media Pembelajaran, , hal. 38.

${ }^{20}$ N. Sudjana \& Rivai, Media Pengajaran,............, hal 16.
} 
Berdasarkan atas beberapa fungsi media pembelajaran yang dikemukakan di atas, maka dapat disimpulkan bahwa penggunaan media dalam kegiatan belajar mengajar memiliki pengaruh yang besar terhadap alat-alat indera. Terhadap pemahaman isi pelajaran, secara nalar dapat dikemukakan bahwa dengan penggunaan media akan lebih menjamin terjadinya pemahaman yang lebih baik pada siswa. Peserta didik yang belajar lewat mendengarkan saja akan berbeda tingkat pemahaman dan lamanya "ingatan" bertahan, dibandingkan dengan murid yang belajar lewat melihat atau sekaligus mendengarkan dan melihat. Media pembelajaran juga mampu membangkitkan dan membawa murid ke dalam suasana rasa senang dan gembira, di mana ada keterlibatan emosianal dan mental. Tentu hal ini berpengaruh terhadap semangat mereka belajar dan kondisi pembelajaran yang lebih hidup, yang nantinya bermuara kepada peningkatan pemahaman pebelajar terhadap materi ajar.

4. Klasifikasi Media Dalam Pendidikan Islam

Dengan masuknya berbagai pengaruh ke dalam dunia pendidikan (misalnya teori/konsep baru dan teknologi), media pendidikan (pembelajaran) mengalami perkembangan dan tampil dalam berbagai jenis dan format, dengan masing-masing ciri dan kemampuannya sendiri. Dari sinilah kemudian timbul usaha-usaha untuk melakukan klasifikasi atau pengelompokan media, yang mengarah kepada pembuatan taksonomi media pendidikan/pembelajaran. Usaha-usaha ke arah taksonomi media tersebut telah dilakukan oleh beberapa ahli. Rudy Bretz, sebagaimana dikutip kembali oleh Sadiman, mengklasifikasikan media berdasarkan unsur pokoknya yaitu suara, visual (berupa gambar, garis, dan simbol), dan gerak. Di samping itu juga, Bretz membedakan antara media siar (telecommunication) dan media rekam (recording). Dengan demikian, media menurut taksonomi Bretz dikelompokkan menjadi 8 kategori: 1) media audio visual gerak, 2) media audio visual diam, 3) media audio semi gerak, 4) media visual gerak, 5) media visual diam, 6) media semi gerak, 7) media audio, dan 8) media cetak. ${ }^{21}$

Pengelompokan menurut tingkat kerumitan perangkat media, khususnya media audio-visual, dilakukan oleh C.J Duncan, dengan menyususn suatu hirarki. Dari hirarki yang digambarkan oleh Duncan dapat ditarik suatu kesimpulan bahwa semakin tinggi tingkat hirarki suatu media, semakin rendah satuan biayanya dan semakin khusus sifat penggunaannya. Namun demikian, kemudahan dan keluwesan penggunaannya semakin bertambah. Begitu juga sebaliknya, jika suatu media berada pada hirarki paling rendah. ${ }^{22}$ Schramm juga melakukan

${ }^{21}$ Sadiman, Media Pendidikan: Pengertian, Pengembangan Dan Pemanfaatannya hal. 29.

${ }^{22}$ Sadiman, Media Pendidikan: Pengertian, Pengembangan Dan Pemanfaatannya, , hal. 30 
pegelompokan media berdasarkan tingkat kerumitan dan besarnya biaya. Dalam hal ini, menurut Schramm ada dua kelompok media yaitu big media (rumit dan mahal) dan little media (sederhana dan murah). Lebih jauh lagi ahli ini menyebutkan ada media massal, media kelompok, dan media individu, yang didasarkan atas daya liput media. ${ }^{23}$

Gagne sebagaimana dikutip kembali oleh Anderson, mengelompokkan media berdasarkan tingkatan hirarki belajar yang dikembangkannya. Menurutnya, ada 7 macam kelompok media seperti: benda untuk didemonstrasikan, komunikasi lisan, media cetak, gambar diam, gambar gerak, film bersuara, dan mesin belajar. ${ }^{24}$ Briggs mengklasifikasikan media menjadi 13 jenis berdasarkan kesesuaian rangsangan yang ditimbulkan media dengan karakteristik siswa. Ketiga belas jenis media tersebut adalah: objek/benda nyata, model, suara langsung, rekaman audio, media cetak, pembelajaran terprogram, papan tulis, media transparansi, film bingkai, film $(16 \mathrm{~mm})$, film rangkai, televisi, dan gambar (grafis). ${ }^{25}$

Sejalan dengan perkembangan teknologi, maka media pembelajaran pun mengalami perkembangan melalui pemanfaatan teknologi itu sendiri. Berdasarkan perkembangan teknologi tersebut, Arsyad mengklasifikasikan media atas empat kelompok:

a. Media hasil teknologi cetak.

b. Media hasil teknologi audio-visual.

c. Media hasil teknologi berbasis computer.

d. Media hasil gabungan teknologi cetak dan komputer. ${ }^{26}$

Seels dan Glasgow, sebagaimana dikutip kembali oleh Arsyad, membagi media ke dalam dua kelompok besar, yaitu: media tradisional dan media teknologi mutakhir. ${ }^{27}$ Pilihan media tradisional berupa media visual diam tak diproyeksikan dan yang diproyeksikan, audio, penyajian multimedia, visual dinamis yang diproyeksikan, media cetak, permainan, dan media realia. Sedangkan pilihan media teknologi mutakhir berupa media berbasis telekomunikasi (misal teleconference) dan media berbasis mikroprosesor (misal: permainan komputer dan hypermedia).

Dari beberapa pengelompokkan media yang dikemukakan di atas, tampaknya bahwa hingga saat ini belum terdapat suatu kesepakatan tentang klasifikasi (sistem taksonomi) media yang baku. Dengan kata lain, belum ada taksonomi media yang berlaku umum dan mencakup

\footnotetext{
${ }^{23}$ Ibid, hal. 31.

${ }^{24}$ R.H. Anderson, Pemilihan Dan Pengembangan Media Untuk Pembelajaran, pent: Yusuf Hadi dkk, (Jakarta: Rajawali, 1987), hal. 27.

25 Ibid, hal. 28.

${ }^{26}$ Arsyad, Media Pembelajaran,................, hal. 35.

27 Ibid.
} 
segala aspeknya, terutama untuk suatu sistem instruksional (pembelajaran). Meskipun demikian, apa dan bagaimana cara yang ditempuh dalam mengklasifikasikan media, semuanya memberikan informasi tentang spesifikasi media yang perlu diketahui. Pengelompokan media yang sudah ada pada saat ini dapat memperjelas perbedaan tujuan penggunaan, fungsi dan kemampuannya, sehingga bisa dijadikan pedoman dalam memilih media yang sesuai untuk suatu pembelajaran tertentu.

5. Karakteristik Media Pembelajaran Dalam Pendidikan Islam

Setiap media pembelajaran memiliki karakteristik tertentu, yang dikaitkan atau dilihat dari berbagai segi. Schramm, sebagaimana dikutip kembali oleh Sadiman, melihat karakteristik media dari segi ekonomisnya, lingkup sasaran yang dapat diliput, dan kemudahan kontrolnya oleh pemakai. ${ }^{28}$ Karakteristik media juga dapat dilihat menurut kemampuannya membangkitkan rangsangan seluruh alat indera. Dalam hal ini, pengetahuan mengenai karakteristik media pembelajaran sangat penting artinya untuk pengelompokan dan pemilihan media.

Gerlach dan Ely, sebagaimana dikutip kembali oleh Arsyad, mengemukakan tiga karakteristik media berdasarkan petunjuk penggunaan media pembelajaran untuk mengantisipasi kondisi pembelajaran di mana guru tidak mampu atau kurang efektif dapat melakukannya. Ketiga karakteristik atau ciri media pembelajaran tersebut adalah:

a. Ciri fiksatif, yang menggambarkan kemampuan media untuk merekam, menyimpan, melestarikan, dan merekonstruksi suatu peristiwa atau obyek;

b. Ciri manipulatif, yaitu kamampuan media untuk mentransformasi suatu obyek, kejadian atau proses dalam mengatasi masalah ruang dan waktu. Sebagai contoh, misalnya proses larva menjadi kepompong dan kemudian menjadi kupu-kupu dapat disajikan dengan waktu yang lebih singkat (atau dipercepat dengan teknik time-lapse recording). Atau sebaliknya, suatu kejadian/peristiwa dapat diperlambat penayangannya agar diperoleh urut-urutan yang jelas dari kejadian/peristiwa tersebut;

c. Ciri distributif, yang menggambarkan kemampuan media mentransportasikan obyek atau kejadian melalui ruang, dan secara bersamaan kejadian itu disajikan kepada sejumlah besar siswa, di

${ }^{28}$ Sadiman, Media Pendidikan: Pengertian, Pengembangan Dan Pemanfaatannya,................, hal. 43.

- Moh. Irmawan Jauhari - 77 
berbagai tempat, dengan stimulus pengalaman yang relatif sama mengenai kejadian tersebut. ${ }^{29}$

Secara garis besar media pembelajaran dapat diklasifikasikan atas: media grafis, media audio, media proyeksi diam (hanya menonjolkan visual saja dan disertai rekaman audio), dan media permainan-simulasi. Masing-masing kelompok media tersebut memiliki karakteristik yang khas dan berbeda satu dengan yang lainnya.

Pertama Media grafis. Pada prinsipnya semua jenis media dalam kelompok ini merupakan penyampaian pesan lewat simbul-simbul visual dan melibatkan rangsangan indera penglihatan. ${ }^{30}$ Karakteristik yang dimiliki adalah: bersifat kongkret, dapat mengatasi batasan ruang dan waktu, dapat memperjelas suatu masalah dalam bidang masalah apa saja dan pada tingkat usia berapa saja, murah harganya dan mudah mendapatkan serta menggunakannya, terkadang memiliki ciri abstrak (pada jenis media diagram), merupakan ringkasan visual suatu proses, terkadang menggunakan simbul-simbul verbal (pada jenis media grafik), dan mengandung pesan yang bersifat interpretatif.

Kedua media audio. Hakekat dari jenis-jenis media dalam kelompok ini adalah berupa pesan yang disampaikan atau dituangkan ke dalam simbul-simbul auditif (verbal dan/atau non-verbal), yang melibatkan rangsangan indera pendengaran. ${ }^{31}$ Secara umum media audio memiliki karakteristik atau ciri sebagai berikut: mampu mengatasi keterbatasan ruang dan waktu (mudah dipindahkan dan jangkauannya luas), pesan/program dapat direkam dan diputar kembali sesukanya, dapat mengembangkan daya imajinasi dan merangsang partisipasi aktif pendengarnya, dapat mengatasi masalah kekurangan guru, sifat komunikasinya hanya satu arah, sangat sesuai untuk pengajaran musik dan bahasa, dan pesan/informasi atau program terikat dengan jadwal siaran (pada jenis media radio).

Ketiga media proyeksi diam. Beberapa jenis media yang termasuk kelompok ini memerlukan alat bantu (misal proyektor) dalam penyajiannya. Ada kalanya media ini hanya disajikan dengan penampilan visual saja, atau disertai rekaman audio. ${ }^{32}$ Karakteristik umum media ini adalah: pesan yang sama dapat disebarkan ke seluruh siswa secara serentak, penyajiannya berada dalam kontrol guru, cara penyimpanannya mudah (praktis), dapat mengatasi keterbatasan ruang, waktu, dan indera, menyajikan obyek -obyek secara diam (pada media dengan penampilan visual saja), terkadang dalam penyajiannya

\footnotetext{
${ }^{29}$ Arsyad, Media Pembelajaran,............., hal, 37.

30 Ibid.

${ }^{31}$ Arsyad, Media Pembelajaran,............., 37

32 Ibid.
} 
memerlukan ruangan gelap, lebih mahal dari kelompok media grafis, sesuai untuk mengajarkan keterampilan tertentu, sesuai untuk belajar secara berkelompok atau individual, praktis dipergunakan untuk semua ukuran ruangan kelas, mampu menyajikan teori dan praktek secara terpadu, menggunakan teknik-teknik warna, animasi, gerak lambat untuk menampilkan obyek/kejadian tertentu (terutama pada jenis media film), dan media film lebih realistik, dapat diulang-ulang, dihentikan, dsb., sesuai dengan kebutuhan.

Keempat media permainan dan simulasi. Ada beberapa istilah lain untuk kelompok media pembelajaran ini, misalnya simulasi dan permainan peran, atau permainan simulasi. Meskipun berbeda-beda, semuanya dapat dikelompokkan ke dalam satu istilah yaitu permainan. ${ }^{33}$ Ciri atau karakteristik dari media ini adalah: melibatkan pebelajar secara aktif dalam proses belajar, peran pengajar tidak begitu kelihatan tetapi yang menonjol adalah aktivitas interaksi antar pebelajar, dapat memberikan umpan balik langsung, memungkinkan penerapan konsepkonsep atau peran-peran ke dalam situasi nyata di masyarakat, memiliki sifat luwes karena dapat dipakai untuk berbagai tujuan pembelajaran dengan mengubah alat dan persoalannya sedikit saja, mampu meningkatkan kemampuan komunikatif pebelajar, mampu mengatasi keterbatasan pebelajar yang sulit belajar dengan metode tradisional, dan dalam penyajiannya mudah dibuat serta diperbanyak.

\section{Penutup}

Media pembelajaran adalah segala sesuatu yang menyangkut software dan hardware yang dapat digunakan untuk meyampaikan isi materi ajar dari sumber belajar ke pebelajar (individu atau kelompok), yang dapat merangsang pikiran, perasaan, perhatian dan minat pebelajar sedemikian rupa sehingga proses belajar (di dalam/di luar kelas) menjadi lebih efektif. Dalam awal perkembangannya, media memiliki posisi sebagai alat bantu dalam kegiatan pembelajaran, yaitu alat bantu mengajar bagi guru (teaching aids). Sebagai alat bantu dalam mengajar, media diharapkan dapat memberikan pengalaman kongkret, motivasi belajar, mempertinggi daya serap dan retensi belajar siswa. Media adalah bagian integral dari proses belajar mengajar. penggunaan media pembelajaran dikaitkan dengan apa yang mungkin tidak mampu dilakukan oleh guru (atau guru melakukannya kurang efisien). Fungsi media pembelajaran dalam kegiatan belajar mengajar memiliki pengaruh yang besar terhadap alat-alat indera. Penggunaan media akan lebih menjamin terjadinya pemahaman dan retensi yang lebih baik terhadap isi pelajaran. Media pembelajaran juga mampu membangkitkan dan membawa murid ke dalam suasana rasa 
senang dan gembira, di mana ada keterlibatan emosianal dan mental. Setiap jenis media memiliki karakteristiknya yang khas, yang dikaitkan atau dilihat dari berbagai segi (misalnya dari segi ekonomisnya, lingkup sasaran yang dapat diliput, dan kemudahan kontrolnya oleh pemakai, menurut kemampuannya membangkitkan rangsangan seluruh alat indera, dan petunjuk penggunaannya untuk mengatasi kondisi pembelajaran). Secara umum media pembelajaran memiliki tiga karakteristik atau ciri yaitu: a) ciri fiksatif, yang menggambarkan kemampuan media untuk merekam, menyimpan, melestarikan, dan merekonstruksi suatu peristiwa atau obyek; b) ciri manipulatif, yaitu kamampuan media untuk mentransformasi suatu obyek, kejadian atau proses dalam mengatasi masalah ruang dan waktu.; c) ciri distributif, yang menggambarkan kemampuan media mentransportasikan obyek atau kejadian melalui ruang, dan secara bersamaan kejadian itu disajikan kepada sejumlah besar siswa, di berbagai tempat, dengan stimulus pengalaman yang relatif sama mengenai kejadian tersebut.

Penggunaan media dalam pendidikan Islam adalah sebuah keharusan, sebagai bentuk respon dari berkembang dengan pesatnya tekhnologi yang ada. Hanya saja kemudian, media harus diletakkan dalam wilayahnya secara proporsional, artinya ketika awal mula media hanya sebagai alat bantu untuk para guru dalam upayanya transformasi maupun transfer pengetahuan sudah sepantasnyalah posisi media tidak berubah menjadi hal yang menggantikan peran sentral dari guru itu sendiri. Meski media belakangan mampu menembus dan memberikan informasi lebih banyak dari yang diberikan oleh guru, namun media belum mampu dan tidak dapat menjalankan tugas sebagai pembimbing seperti yang tengah diemban oleh guru. Karenanya tidak mengherankan kalau kemudian terjadi over laping di tingkatan para peserta didik. Mereka menjadi lebih pandai dari guru mereka sendiri secara kognitif, namun dari behaviour, dan afektif, mereka kemudian mengalami keterasingan dengan yang namanya tata krama. Padahal taksonomi tujuan diadakannya pendidikan nasional adalah mencerdaskan kehidupan anak bangsa baik jiwa dan raganya.

\section{DAFTAR PUSTAKA}

Anderson, R.H., Pemilihan Dan Pengembangan Media Untuk Pembelajaran, pent: Yusuf Hadi dkk, Jakarta: CV. Rajawali, 1987.

Anggoro, M. Linggar, Teori Dan Profesi Kehumasan Serta Aplikasinya Di Indonesia, Jakarta: Bumi Aksara, 2001.

Arsyad, A., Media Pembelajaran, Jakarta:Grafindo Persada, 2002.

Darajat, Zakiah, Ilmu Pendidikan Islam, Jakarta: Bumi Aksara, 1984. 
Hamalik, O. Media Pendidikan, Bandung: Citra Aditya Bakti, 1994.

N. Sudjana \& Rivai, Media Pengajaran, Bandung: CV. Sinar Baru Bandung, 1992.

Ramayulis dan Syamsul Nizar, Filsafat Pendidikan Islam, Jakarta: Kalam Mulia, 2009.

Rosady Ruslan, Manajemen Public Relations Dan Media Komunikasi, Jakarta: Raja Grafindo Persada, 2007.

Sadiman A.S. dkk, Media Pendidikan: Pengertian, Pengembangan Dan Pemanfaatannya, Jakarta: CV. Rajawali, 1990.

www.wordpress.com media pembelajaran. Diunduh tgl 14 Januari 2015. www.wordpress.com pendidikan konstruktivisme,diunduh tgl 12-12-2015. 